\title{
FEMALE BODY, DISCURSIVE THREADS AND THE "SLUTWALK" MOVEMENT
}

\section{CORPO FEMININO, ENLACES DISCURSIVOS E MOVIMENTO "MARCHA DAS VADIAS"}

\author{
Guilherme Figueira-Borges $^{1}$
}

\begin{abstract}
This article aims at establishing an analysis of the "SlutWalk" event that took place in Uberlândia, Minas Gerais state, Brazil, on March 9th 2013, outlining a construction of another female body in history. In order to do so, the article is based on the French Discourse Analysis, specifically on Foucault (1996, 2001a, 2001b, 2008, 2011, 2013), Paveau (2018a, 2018b) and Nietzsche (1996, 1998, 2001, 2004 e 2009). Firstly, the "SlutWalk" movement is highlighted as an event that destabilizes powers and ressignifies the female body in history. Next, a dialog with the Nietzschean notion of body is established as well as some considerations made by him about women in society. From this study, it was outlined that the female body, in the target movement and discursively, is based on an externality that focuses on the materiality of the bodies from language functioning.

KEYWORDS: Female body; Discourse; SlutWalk.
\end{abstract}

\section{RESUMO}

Neste artigo, objetivo estabelecer uma análise do acontecimento "Marcha das Vadias" que ocorreu na cidade de Uberlândia, Minas Gerais, no dia 09 de março de 2013, delineando a construção de um corpo feminino outro na história. Para tanto, há a inscrição no campo da Análise do Discurso francesa especificamente nos trabalhos de Foucault (1996, 2001a, 2001b, 2008, 2011, 2013), Paveau (2018a, 2018b) e um diálogo com o pensamento de Nietzsche (1996, 1998, 2001, 2004 e 2009). Em um primeiro momento, destaco o movimento "Marcha das Vadias" enquanto um acontecimento que desestabiliza poderes e ressignifica o corpo feminino na história. Em seguida estabeleço um diálogo com a noção nietzschiana de corpo e apresento algumas considerações tecidas por ele sobre as mulheres na sociedade. A partir deste estudo, delineou-se que o corpo feminino, no movimento em questão, discursivamente, funda-se a partir de uma exterioridade que incide sobre a materialidade dos corpos a partir de um funcionamento da linguagem.

PALAVRAS CHAVE: Corpo feminino; Discurso; Marcha das Vadias.

Women have served all these centuries as looking glasses possessing the magic and delicious power of reflecting the figure of a man at twice its natural size $e^{2}$. Virginia Woolf (1992, p. 54)

I have been focusing on the body constitution for some time, not on a biological or physiological perspective but as a discursive instance in which the subject constitutes himself/herself. As a result, Virginia Woolf's utterances are valuable to me, not only because they deal with an historical asymmetry between men and women but mostly because such asymmetry

\footnotetext{
${ }^{1} \mathrm{PhD}$ in Linguistic Studies by the Federal University of Uberlandia, professor of the Language Institute of the Goias State University - Morrinhos Campus and of the Graduate Program in Language Studies PPGEL - UFCat. Leader of the "Discourse and Nietzsche Study Group GEDIN/CNPq. Email: guilherme.borges@ueg.br

2 Translation of the original version in French: "Les fammes ont pendant des siècles servi aux hommes de miroirs, elles possédaient le pouvoir magique et délicieux de réfléchir une image de l'homme deux fois plus grande que nature" (WOOLF, 1992, p. 54).
} 
goes through a corporeal constutivity. I believe it is not a heresy to say that the female body has been a space that reflects a male constitution throughout history, showing marks/rests of a virility built outside women, but that reflects on the borders of a female body, establishing a subject.

On the present study, I aim to analyzing the event called "Slut Walk", which took place in Uberlandia, state of Minas Gerais, Brazil, on March 09th, 2013. This movement interpellated me regarding the emergence of a singularity when it comes to showcasing the female body in two aspects: (i) because it presents a female body with partial nudity (only breasts shown); (ii) because these bodies form a writing surface. Some issues guided my interpellation such as, if there is a political (and therefore ideological and historical) control over bodies, what is the mechanics of this exercise of power? What to think about a female body that resists power relations? How to think the interweaving between body and speech? How could one take the body not as "a simple medium upon which slogans [pictures, utterances] would be written, but the medium in which inscriptions are realized"? (Our emphasis) (PAVEAU, 2018b, p. 3). Being a very contemporary movement, the Slut Walk, still echoing in some cities of Brazil, with this study I want to present some indications addressing these issues, without the urge of presenting definitive answers.

It may be said, in the guise of what Foucault argues about punitive systems, that "the body is also directly plunged into a political field; power relations have an immediate reach over it; they invest, mark and direct their bodies; subject them to works, force them into ceremonies, demand signs "(Foucault, 2011, 28). In this sense, the female body is a knot in a complex network of relations of power and domination that mark social practices and dictate what can and should be said, as well as what can and should be worn. In the event founded by the "Slut Walk," it can be said "women have made their bodies a means that constitute a weapon in their struggle for emancipation, equality, parity and, above all, respect and integrity "(PAVEAU, 2018a, p.1).

In this sense, it is important to focus on the description of the Slut Walk movement as an event that founds and disseminates discourses in society. An event understood, in this work, as corporal practices carried out by female bodies and that give new meaning to women's role in the society.

On March 9th, 2013, the first Slut Walk of Uberlândia, Minas Gerais, was formed. Countless subjects carried posters with words of support for a new face of the feminist movements, among these subjects some stood out in the measure in which their own bodies were carriers of such sayings. The subjects allowed their bodies to be written on, discursively marking their bodies in history. I consider it relevant to say that, unlike the tattoo that is lasting writing, these subjects write their own bodies in ink, which remarks the ephemerality of such writing. However, it can be said that writing does not pass through the body without leaving historical remains in the constitution of the subjects and that are perpetuated in the photographs I took; some to be analyzed. Writing and body, in this event, merge in a singular effect symbiosis.

The movement called "SlutWalk", globally renowned, emerged in Canada, when, in January of 2011, a police officer, based on the high number of rapes that were happening, has said that women should avoid dressing themselves as "sluts" to prevent being violated. In the utterance of the police officer, there is a shift of the female body, from a victim position to a position that installs aggression, the body as the one that causes the rape practice. Thus, I see an echo in the police officer words, social-historical-ideological voices that were socially crystallized and said to be truth in history. These voices dictate and legitimate certain practices for the female body, relegating to ostracism all that is out of the current truth. The female body, for this police officer, is no longer the one testifying against the physical aggression but the one on the defendant's seat, being accused of assaulting the moral.

In case the female body that subverts to the rule is called "slut", there is nothing better than appropriating of such denomination and ressignify it by proposing a Slut Walk. In such 
appropriation, there are other senses that slide on the word "slut", which are not negative anymore, but of resistance, having, therefore, to be affirmed in the social practices. Such slut-body is one that resists to a pattern of behavior dictated by the moral; it is one that aims to unties the sexist patterns. The slut body is one that does not avoid to fight for another position of the woman in society, a position in which it does not emerge from the fear of assault and rape, which, before being considered crimes, must be considered as violence to the body that remarks not only physical aggression but also a discursive aggression. In the raped body, it remains wounds forged by a memory that beats on the constitution of the violated subjects. The utterances also invade the flesh aiming at satisfying the ephemeral desire (and for so conqueror) of the aggressor.

Based on Paveau (2018), I consider that the Slut Walk institutes the double movement concerning the social positional and the appearance of the female body. According to the author, there is a place shift, as the naked and half-naked female body was destined to brothels or other places destined to male pleasure, being interdicted, and not to be exposed in the streets. Another displacement concerns the historically constructed female body appearance throughout history: the institution of garments, makeup and perfumes. The female body was educated for seduction or to concealment (by the male body), and now it becomes a body that fights and resists; undoubtedly a political body.

Then, the female body goes through aestheticism and spatial movements that found another face for the subject woman. In estheticism, the female body is decomposed, rethought in each of its parts and reorganized in history in relation to the clothes in which it can be dressed, the organization and hair color and even the tattoos that are allowed and encouraged in contemporaneity. The space for the female body is no longer that utopian, bucolic; romantic but that heterotopic, imperfect, with fissures in which women emerge as desired bodies. It can be said that the slut-body emerges in a disconcerting game that moves history at the same time that it is caused by it.

Paveau (2018b, p. 02), when analyzing Femen, a Ukrainian group, similar to the Slut Walk: "the real body is, effectively, signified by the exposition to its breast and, certainly, out of previously reductions they are only breasts [...] A breast-body specie (our highlights). I share the author's position about the singularity of the exposed bodies, highlight breasts in public ressignify the female body, However, I do not see them only as breasts, because I see a symbiosis between body(-breast) and writing. It is undeniable that, in the cases analyzed by Paveau (2018b), as well as in those ones that I highlight, the writing that goes through the bodies significantly contributes to the senses that slide the highlighted bodies. The superposition between the breast and the utterance goes around a soul-body that intensely surrenders to militancy.

I consider it relevant to focus, even briefly, some Slut Walk invitation folders.
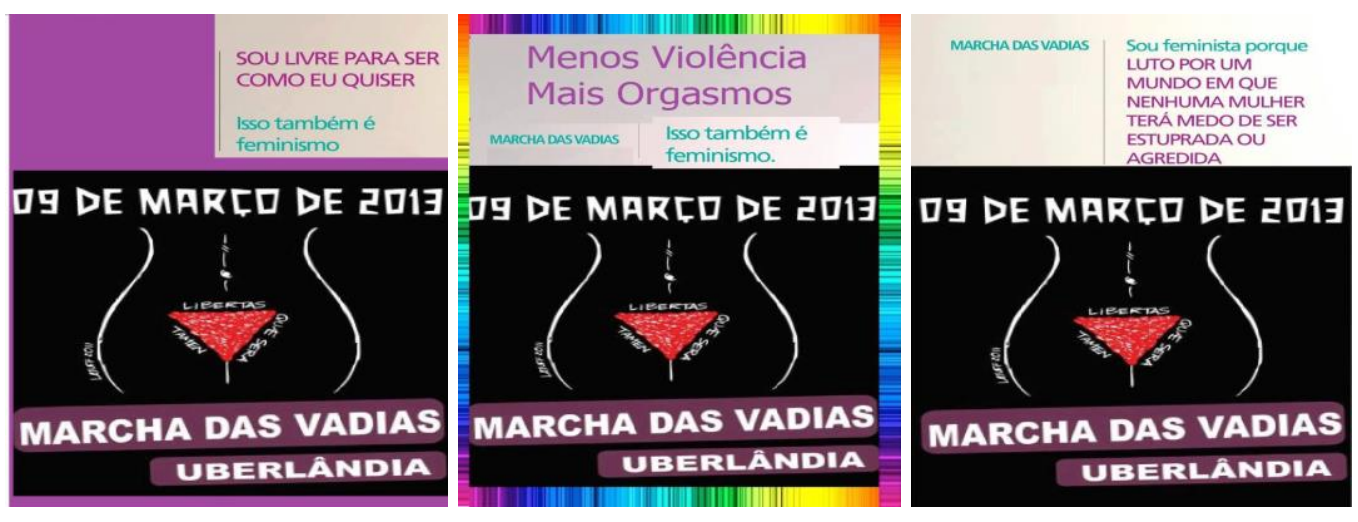

\footnotetext{
3 Translation of the French original: “corps réel est effectivement signifié par l'exposition de leurs seins, et, d'une certaine manière, mais en dehors des réductions précédentes, oui, elles ne sont que des seins [...] Une sorte de corpsseins" (PAVEAU, 2018b, p. 02).
} 
Fonte: https://www.facebook.com/pages/Marcha-das-Vadias-Uberlândia/244506805679189 Accessed on October 18th, 2018.

In the folders, centrally, is presented a drawing of a female body in whose genitalia I see an inversion of the symbols of the flag of the state of Minas Gerais. According to Foucault (1996), the principle of inversion occurs in the change of position from which it is no longer the objective of the author's gaze and/or the subject as the owner and master of his utterances, that is, in discursive practices, in the "negative play of a cut, and in a rarefaction of discourses" (Foucault 1996: 52). The inversion is only possible through questioning the specificity of the female body; it is no longer regarded as a divine object, but rather as a historical construction being a knot of a complex network of knowledge and powers.

It may be said, in this sense, that there is inversion in at least three distinct points: (i) while the bottom of the flag is predominantly white, the body is black; (ii) the central triangle of the flag is on the genitalia and inverted; (iii) the words that give margin to the genitalia are in another order, since "libertas" is in the inverted base. This inversion marks another imaginary for the female body, demarcating a position that emerges as a possibility of historical discontinuity. This discontinuity enables a rearrangement in the power relations that affect the female body.

I think this reversal establishes a refraction of the Venus symbol. I understand the refraction as a deviation in the sense that slides on the materiality of the slut-body. I say refraction because if, mythologically, Venus represents the feminine, the sensibility, the abstention, the senses that slide on the triangle institute a strong female body, that gives birth, worthy of respect and liberations; the obligations that have been attributed to it in history such as maternity. What marks this liberation, as an object of desire is the position of the Latin word "libertas" which occupies a prominent position on the edge of the female genitalia. I think there is juxtaposition between "freedom" and "clitoris," the freedom forged in this drawing is considered a subject practice for oneself that can provide pleasure and, above all, lead to orgasm.

Once this re-signification of the female body is highlighted, from this moment on I consider it relevant to establish a dialogue with the Nietzsche's thinking, since he was a voracious critic of women's submission in history.

Zarathustra, as the spokesman of the Nietzschean theory, says that an awaken man claims: "all of me is body and nothing else; the soul is no more than a name to call something of the body"(NIETZSCHE, 2008, p. 51). The awaken subject mentioned by Nietzsche would be the one that affirms his constitution as a multiplicity of strengths that contours the body. On a Nietzschean perspective, the self would not be responsible for the delimitation of the body, but the body in its fullness of strengths fighting that emerges a "me" in space and time. Under such perspective, the body is "a multiplicity with only one sense, war and peace, flock and shepherd"(NIETZSCHE, 2008 , p. 51). In the utterances of Zarathustra that I mention, there is an issue that I consider relevant, the language seeks to say "call something of" the body. For Nietzsche, thinking the body is also to think about language, because talking about the body means, metaphorizing and interpreting it.

The subject has unnoticed access to the body through language; however, language cannot represent the body in its complex war of strengths. Language can only represent the victorious wars, the dominated and dominant forces, Nietzsche mentions, "what we call consciousness is a somewhat fantastic comment about an unknown text, maybe not "known", but felt? (NIETZSCHE, 2004, p. 93). Under a Nietzschean perspective, language is simulacrum, flawed and, above all, of a nature different from the body, for this reason, there are body compositions and combinations that are not known to the subjects due to an incompleteness of language. According to Nietzsche (2004), 
the words are in our way! - Where the ancient men out one word, they believed they had discovered. Actually, how different it was! - They had touched a problem, and, supposedly having solved it, they had created an obstacle for the solution. - Now, in each event we bump into eternalized words, hard as rocks, and it is easier to break a leg than a word (NIETZSCHE, 2004, p. 43)

The practice of creating words, and, as a consequence, creating concepts that seek to work with reality, pilfers a constitutive hiatus between language and open body in history by the subjects. From the illusion called by Nietzsche (2004) "Fantastic", which language can represent body, the subjects move in social practices towards morality. According to the same author, "we will not escape from God because we still believe in grammar..." NIETZSCHE, 2009, p. 38). This belief represents identification from men to the grammatical subject, to a subject dominated of his practices, represented by verbs, as well as his consequences. To believe in a grammatical subject is to believe in a unique subject that presents a divine essence in which he might be, illusionarily, image and similarity. Under a Nietzschean perspective, there is no one essence in subject constitution, nor he is dominator of his body, on the other hand, actually is the body that founds himself as a subject on a strength continuum in the world.

The Nietzschean criticism to the language completeness, unfolds on the body notion, since an essence cannot be thought, an initial substance for the body, on the contrary, a look is installed for the body, and the image formed is of interpretations that tend to infinite. In The Gay Science, Nietzsche (2001) states that "the world became once more "infinite" to us: since we cannot reject the possibility of it to conclude infinite interpretations (our emphasis) (NIETZSCHE, 2001, p. 278).

In fact, I can say that the female body interpellates me to generate countless interpretations about its constitution and, as mentioned before, there are processes of its constitutions inaccessible to the subjects' consciousness due to the incompleteness of language. There is no one essence for the female body, on the contrary, this body was destined in history (through power relations) to docilization, meekness, and domestication. For Nietzsche: "men ruin women" NIETZSCHE, 2001, p. 100), postulating, as well, that "all women's failures must be explained and corrected by men - because the man creates for himself the image of the woman, and the woman creates herself according to such image" (NIETZSCHE, 2001, p. 100).

I consider it relevant to say at this time that I do not deny the fact that the Nietzsche's claims provide a biological view of the female body as it can be seen in some of the aphorisms of The Gaia Science. Rather, I want to work on another possibility of analyzing Nietzsche's theory from a notion of the discursive body.

In this attempt, I consider it relevant to present a priori a study by Deleuze (2001) on a possible notion of body in Nietzsche, with which I feel (in)tensely interpellated by:

\footnotetext{
What is the body? We do not define it by saying that it is a field of forces, a nutritious medium in which a plurality of forces are disputed. In fact, there is no 'means', field of forces or battle. There is no amount of reality; any reality is already an amount of force. Only amounts of force 'in relation to tension' with each other. (...) Any two forces, being unequal, constitute a body from the moment they enter into relation: that is why the body is always the result of chance, in the Nietzschean sense, and it appears as the most 'surprising' thing, much more surprising in truth than conscience and spirit (DELEUZE, 2001, pp. 62-63)
}

It is the case, in this sense, I believe, to think first of what "force", "will" are according to Nietzsche, and then think about its relationship with the female body. The notion of force in Deleuze's interpretation of Nietzsche is embedded with a notion of meaning, considering that it is not possible to describe the meaning of an element in the world without first revealing what force dominates it. In this way, "the history of a thing is usually the succession of the forces that take 
possession of it, and the coexistence of the forces that fight for it takes over" (DELEUZE, 2001, p. 9).

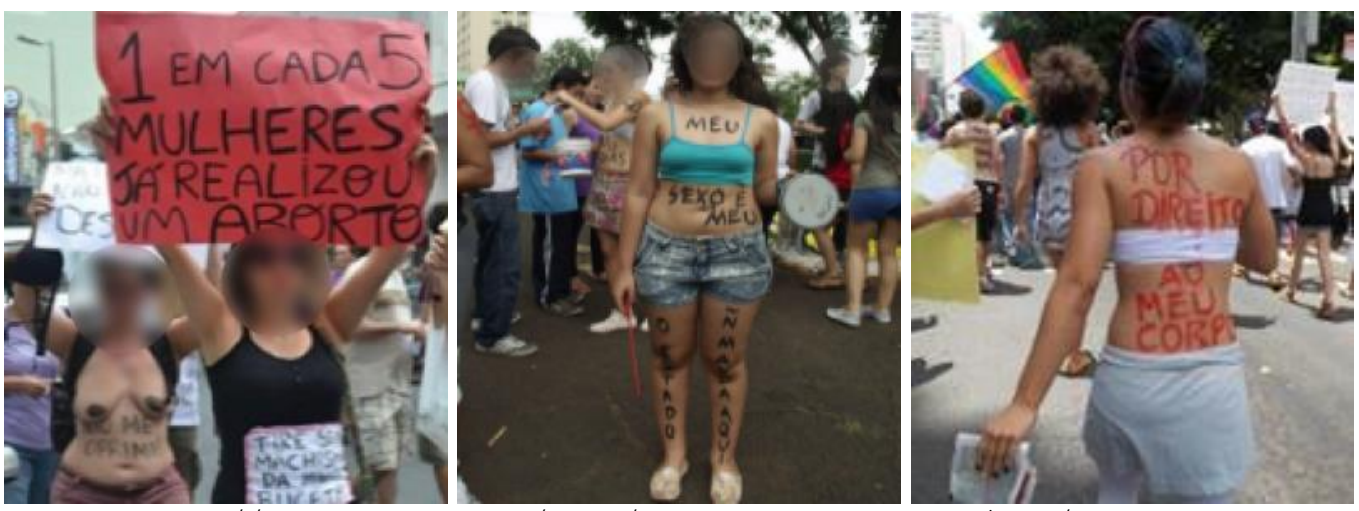

Source: https://www.facebook.com/pages/Marcha-das-Vadias-Uberlândia/244506805679189 Accessed on October, 18th, 2018.

The meaning that is interpreted from things in the world escapes a much greater event, since it unveils the dominant force and rekindles it to fight, the one that beats it, as well as the defeated force that awaits the rematch in the fight. Deleuze (2001) points out that one can not yield to the temptation to interpret plurality in the form of a secession in time and space of good, evil, truth, lies, revolt and resignation, as if a force could exclude other in the events. The forces are not excluded, but they alternate in the constitution of the subjects which allows me to say the docile and resigned body presents in its constitution also the germ of anger and revolt, ready to emerge in fullness and dominance.

The Slut Walk exposes the belligerent network of forces, changing points of domination in space and time in which the body is constituted. The dominant forces in the female body that I have exposed are others, so the constitution of these subjects are also another. The words, in the ephemerality of writing, move this body to another place, governed by another will to power.

Indeed, a force from a Nietzschean perspective maintains other forces in discontinuous alterity, it may be said metaphorically that forces enjoy a status similar to that of the two faces of a coin which, when thrown upwards by the subject, strive to demarcate what is the winner in the currency and among the subjects, an unquestionable fact is, in kneading one side of this coin, inevitably the other side is kneaded. And in the fall of the coin the sides of the face or the crown and not the coin itself are already seen, likewise, when the subjects relate to a thing in the world, is already related to the force that dominates it, so the object "It itself is not an appearance, but the appearance of a force" (DELEUZE, 2001, p.13).

In this aspect of forces dominating forces in the constitution of the bodies of the world, one can think the force as that which drives a will for power. Similarly, in reality, there are wills prevailing over wills, and every will yearns to exercise power over other wills, to subjugate other wills, and to show that it, as the dominant will, is evoked by the body.

I share the interpretation that, in Nietzsche $(1998,2001,2004)$, there is no body and / or subject before the struggle of forces; on the contrary, it is the complex struggles of force that found the female body and, therefore, the subject. Deleuze (2001) points out that they constitute the chemical, biological, social and political body. For my part, I would like to add something that is lacking in this utterance, namely: the discursive body. To underscore this lack, insofar as I believe that the discursive evokes a singularity another for the nature of a body-beligerance.

I consider it relevant to reaffirm that, in a Foucaultian perspective, as in the Nietzschean, there is no subject lord of her/himself, controller of his speeches and the senses derived from 
them. What is, in social practices, is an intense movement of the subject in positions, evidencing, therefore, a constitution in constant becoming. In this way, there is no "O" subject, but a diversity of positions in which the subject is inscribed to enunciate.

According to Foucault (2001a), discourses present certain plasticity in history, so sometimes the discourses are dynamized and, for others, "the plastic form remains, but it hosts a succession of diverse subjects (the naked woman, who is the addiction in the Middle Ages, becomes denudate Love, therefore pure, true and sacred in the sixteenth century) "(FOUCAULT, 2001a, 649). The discourses that affect the female body move along the thread of history. Which allows me to think that, in the event of the Slut Walk, regarding the plasticity of the female body, another theme is unfolded, crossed by other discourses.

It is worth highlighting that the female body and the utterances that goes through this body are from different nature, however, from the superposition of these two materialities the slut-body as an utterance emerges. As Foucault (2001a) states, when thinking the relation between discourse and image: "the discourse and the image have each one in its way, but they keep complex and tangled relations. It is its mutual functioning that is described" (FOUCAULT, 2001a, p. 650). Concerning Foucault's perspective, the discourse does not confuse with word, linguistic. The discourse is an ephemerality that in flash of time crosses the work filling it of certain senses and not others.

It is considered the discourse as an effect persecuted by the genealogist, it cannot and should not "have been taken as a junction of things that is said, or the way of saying it. It is also in things that are not said, or marked by gestures, by attitudes, by ways of being, by behavior schemes, by spatial movements ${ }^{4}$ (FOUCAULT, 2001b, p. 123). This view of discourse aims at eliminating, as Foucault (2001b) says, the duality between the dominator discourse as the one that exerts the power and discourse of the dominated, while the on in which a power is exerted. It is in and by discourse, considered a microphysics of emergence that the power is exerted by all in the most everyday linguistic practices. The discourse is not what separates a dominant sexism and the feminist movement Slut Walk; the discourse is what unite them viscerally. Thus, discourse and power manifestations imbricate themselves, revealing a positive face for the discourse.

On one hand, we see that discourse does not fully coincide with the word, it is worth saying that, on the other hand, the enunciation and sentence can juxtapose each other, but the enunciation cannot be only reduced to the linguistic materiality of the sentence. Foucault (2013) adds that "language and enunciation are not in the same level of existence" (FOUCAULT, 2013, p. 103). According to the author, language is a system of signs in a difference game that only recognizes its own order. Working only in the language level implies on a detailing an explanation of regularities that affect the sign, but it excludes the subject of the analytical field. Conversely, enunciation is life, it is a subjective and subjectivant manifestation in the time and space flow. The enunciation has to be taken in its complex heterogeneity. This way, the own sentence is structured as so because it bases conceptually in certain enunciations. Foucault (2013) exposes:

\begin{abstract}
What about the sentence? Would it be necessary to admit equivalence between sentence and enunciation? When there is a sentence grammatically isolateable the existence of an independent enunciation can be recognized; but, one cannot talk about enunciation when, under the their own sentence, the level of its constituents is reached [...] However, the equivalence [between the sentence and the enunciation] is far of being total, it is relatively easy to mention enunciations that do not correspond to the linguistic structure of sentences. FOUCAULT (2013, p. 98-99).
\end{abstract}

From what I have presented about the nature of the utterance, I can then begin to think that from the interweaving between bodies and writing a body-statement emerges. Thus, it should

\footnotetext{
4 Translation of: "pris comme l'ensemble des choses qu'on dit, ni comme la manière de les dire. Il est tout autant dans ce qu'on ne dit pas, ou qui se marque par des gestes, des attitudes, des manières d'être, des schémas de comportement, des aménagements spatiaux" (FOUCAULT, 2001b, p. 123).
} 
be said that, in a Foucaultian view, there is no "The" female body, on the contrary, there are movements of wills that unveil a multiple, heterogeneous, cleaved, fragmented body, in short, a body that supports in a passive way) the subjects' movements in their complex social, historical and ideological practices. As Foucault (2008) said in his analysis of the body in the eighteenth century, "from the moment that power produced [the effect of an investment of and on the body], inevitably the claim of its own body against power, health against the economy, pleasure against the moral norms of sexuality, marriage, and modesty emerges "(FOUCAULT, 2008, p.146). It is postulated that "power penetrated the body" (FOUCAULT, 2008, p.146), dictating even the functioning of the organism. Throughout history, power has penetrated the female body and determines its functioning, which makes it possible to think that women do not dominate their bodies, since there are practices that are interdicted, such as abortion.

However, there is no exercise of power without resistance, the female bodies that I analyze claim their own bodies against power. I consider it relevant to point out that, in a Foucaultian perspective, power is not only negative in order to evidence repressions, controls, regulations, power is, on the contrary, affirmative, it produces "positive effects on desire - as one begins to know - and at the level of knowledge "(Foucault, 2008, p 148). It is precisely because there is an effect of power in the female body that the Slut Walk emerges as a possibility in history.

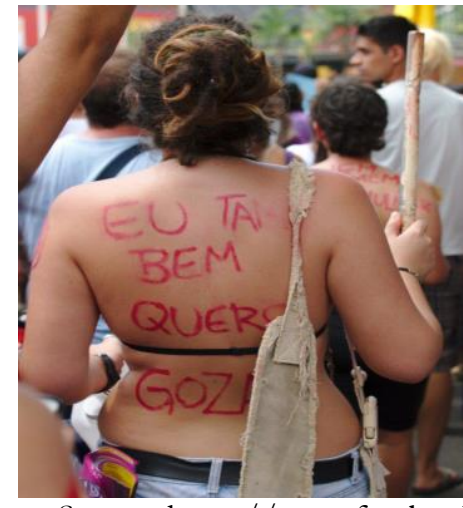

Source: https://www.facebook.com/pages/Marcha-das-Vadias-Ul

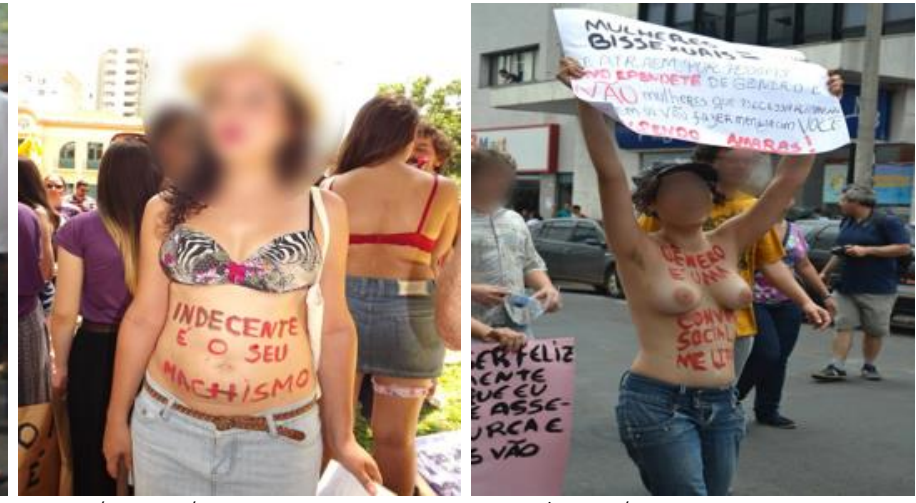

Accessed in October 18th 2018.

The body is, from a discursive point of view, "object and target of power" (FOUCAULT, 2011, 132). Through an exercise of power, the feminine body was a space of control of the wills that constitute it with the purpose of becoming a docile body. In this sense, "it is docile a body that can be submitted, that can be used, that can be transformed and perfected" (FOUCAULT, 2011, 132), which leads me to think that the indolent body present in manifestations seeks to subvert order by reversing the roles assigned to it in history.

These indolent bodies seek to show that there is nothing natural or divine in a subjection to the masculine body, that this practice is only established because "the body is trapped within very tight powers, imposing limitations, prohibitions or obligations" (Foucault, 2011, 132). But other positions do not cease to emerge in history for the inscription of the feminine body, for which insurrection in enabled.

Although Foucault (2011) states that the emergence of the docile body when saying that the "human body enters a power machinery that scrutinizes, dismantles and renews it" (FOUCAULT, 2011, p. 133), I see that a similar process occurs in the indocile-body instauration. In my opinion, the fact that emerges an indocile-body, as an insurrection practice does not impedes other powers to incise on this body. Thus, there is no body uninvolved to power manifestation. If at some points the power is reduced, at other it is exalted in all its existence.

It is worth mentioning that, the female body emerges tensions that oscillate between regularity and dispersion. In regularity, the body will establish and also be established by its own and singular esthetics but that is found anchored to another event, such as the feminist movements 
of the last century, and, on the other hand, I mean dispersion, as the foundation of the female body, the Slut Walk movement, as an intersubective manufestation incorporates itself to other practices and social movements, for example the LGBT Uberlandia, establishing other relations that may tend to infinite.

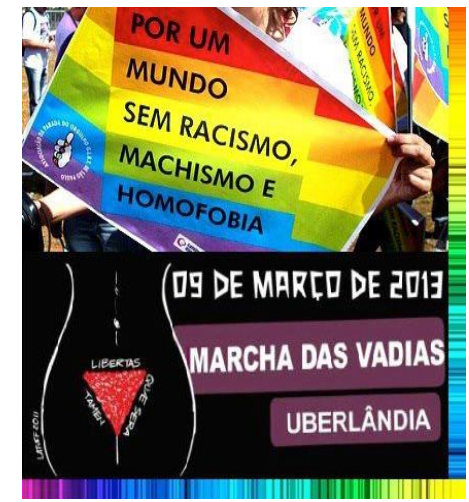

Source: https://www.facebook.com/pages/Marcha-das-Vadias-Uberlândia/244506805679189 Accessed on October 18th, 2018.

As far as I concern, it is necessary to concentrate more in this regularity and dispersion perception as basic aspects of a female body, because I believe that it is in this regularity/dispersion game that the body can be seen, anchoring on a Foucaultian perspective, not as a pessimistic materialization in and by history but affirmative and happy, in the Nietzschean sense of the term, in the (un)ties of the become. I mean happy because there is a surrender to the strengths that impells the body. I also say affirmative because I believe that in the and by the female body there are dispersions that, on one hand, establish asymmetrical relations with other bodies, such as the transvestite-body. I think it is relevant to talk about the body of transvestites because I believe that they also constitute a slut-body, since, as it is a body that also undergoes aesthetic reorganization. However, it is an aesthetic reorganization of another nature, in that there is a (re)modeling of the body itself. The discourses focus on the flesh, transforming a male body into a female one through political, therefore ideological (control) techniques of the body.

The bodies that participate in the Slut Walk are also bodies that surrender to the eyes of other subjects. I think that in the march, also, there is a process of spectacularization of bodies. It should highlight that it is no longer a social exposition of the body that has been impeached, as one of the forces of punishment, as Foucault (2011) stated. In his own words, "the dejected, quartered, amputated body, symbolically marked on the face or on the shoulder, exposed either alive or dead, given as a spectacle, disappears" (Foucault, 2011, p. However, I cannot say that its effects had disappeared, since in the torture, on one hand, the bodies of the convicted could - and in fact were - quartered in a public square so that the crime was not encouraged. On the other hand, the slut-body exposes itself in public ways to interpellated other bodies, also, through example. Thus, this body practice fits into pedagogy of bodies. The spectacularization is the key to the movement, the (semi naked) body needs to be seen and its images propagated so that it becomes (con)figured in the story line, a model body.

Such spectacle of a slut-body emerges as a possibility for a discontinuity in history, through its cracks in which other bodies may always emerge in imposition and resistance to power. Thus, contrary to a pessimistic interpretation, subjects are not doomed to always have the same bodies. The historical discontinuity opens the possibility of a cell exchange, stiffening or sagging muscles, if the story moves, there is no way to ask the body to remain the same. To the subjects, in the socio-historical-ideological practices, there is always the possibility of a resistant, rebellious, revolt body. 
The constitution of a female body occurs, as I pointed out, in an untimely knowledge and power, and on it, unfolds a (re)tie of node(s) of a network of social, ideological and historical practices. In a (re)position of the female body in history, it is necessary for the body to accept the marks of displacement, it is necessary that the untimely feminine body utters and is uttered by the other in the present. The body, in this sense, from the event of the Slut Walk, is (i) repositioned, inscribing the subject in a position of insurrection and militancy; as well as (ii) re-signified in its compositional elements such as, for example, the breast on the capacity of weapons. Through the approximations elaborated with Nietzsche (1998, 2001, 2004) and Foucault (2001a, 2001b, 2008, 2011), I was able to reveal that the body in its discursive dimension does not arise in itself. On the contrary, it is a result of discourses that are external to it and trespass it, giving way to a corporeal aesthetics (organization).

Finally, I would like to say that the slut-body that emerges in contemporaneity shows, on the one hand, a resistance to the existing order and, on the other, the opening of another network of relations of power and knowledge in which, through the female body, a struggle is founded for the illusory control of a corporeal constitutivity. Foucault (2008), however, emphasizes that "one must accept the indefinite nature of the struggle ... which does not mean that it will not end one day" (Foucault, 2008, p. I think, then, that a struggle must break out so that others are (im) possible in the thread of history.

\section{REFERENCE}

DELEUZE, Gilles. Nietzsche e a Filosofia. Porto: Rés-Editora, 2001.

FOUCAULT, Michel. A ordem do discurso. Trad. Bras. 3ed. São Paulo: Edições Loyola, 1996. "Les Mots et les Images". Dits et Écris. V. 1. Paris: Édition Gallimard, 2001a, p. 648651.

"Le discours ne doit pas être pris comme...". Dits et Écris. V. 2. Paris: Édition Gallimard, 2001b, p. 123-124.

Microfísica do Poder. Rio de Janeiro: Edições Graal, 2008.

Vigiar e Punir. Rio de Janeiro: Vozes, 2011.

Arqueologia do Saber. Rio de Janeiro: Florence Universitária, 2013.

NIETZSCHE, Friedrich. Obras Incompletas. São Paulo: Editora nova cultural, 1996.

Assim Falava Zaratustra. Lisboa: Relógios D’Água, 1998.

. A gaia ciência. São Paulo: Companhia das Letras, 2001.

Aurora. São Paulo: Companhia das Letras, 2004.

Crepúsculo dos Í́dolos, ou, Como se Filosofa com o Martelo. Porto Alegre: L\&PM, 2009.

MARTON, Scarlett. Nietzsche - das forças cósmicas aos valores humanos. São Paulo: Brasiliense, 1990.

PAVEAU, Marie-Anne. "Série d'Hiver. Ces Corps Qui Parlent". In: La pensée du discours [Carnet de recherche]. Disponível em: http://penseedudiscours.hypotheses.org/11490. Acesso em: 18 out. 2018 a.

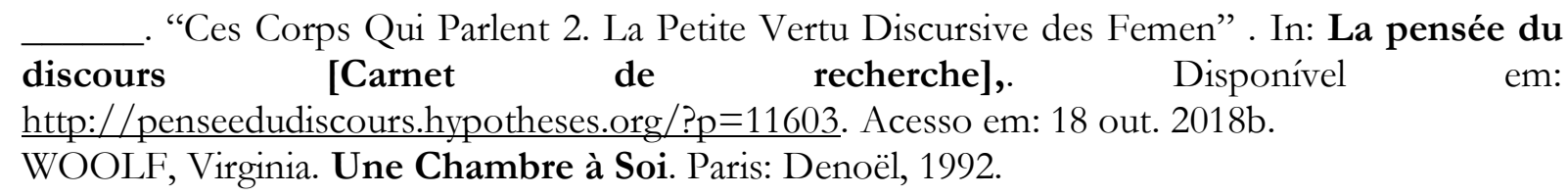

